Águeda Gil López Francisco de Vitoria University (Spain)

Ricardo Zozimo

Lancaster University (UK)

Elena San Román

Complutense University of Madrid (Spain)

Sarah L. Jack

Lancaster University (UK)

\title{
At the Crossroads. Management and Business History in Entrepreneurship Research
}

\begin{abstract}
Recent calls for a historic turn in organization studies offer the opportunity to relaunch dialogue between management and business history research. Focusing on the specific domain of entrepreneurship research, this article illustrates the potential of mutual contributions from management and business history. In doing so, it highlights how historical approaches strongly influenced the early theoretical developments within entrepreneurship and demonstrates the potential to contribute to future scholarly debates. In sum, this article brings closer together business history and management studies stressing that their different perspectives and approaches are very valuable to enriching entrepreneurship research.
\end{abstract}

Keywords: Business History; Management; Entrepreneurship; Literature Review; Historic Turn.

Corresponding author. E-mail: agueda.gil@profesores.ufv.es

Received 26 February 2016 - Accepted 14 March 2016

This is an Open Access article distributed under the terms of the Creative Commons Attribution-Non-Commercial-No Derivatives License (http://creativecommons.org/licenses/by-nc-nd/4.0/), which permits non-comercial re-use and distribution, provided the original work is properly cited, and is not altered or transformed in any way. 


\section{Introduction}

Although it is now generally accepted that "history matters", there are certain areas of inquiry in which dialogue between management theories and business history remains undeveloped. Entrepreneurship is an outstanding example. As Jones (2008) asserted, "despite having too much to offer the study of entrepreneurship and management, business history has developed in a separated silo". The declining attention to historical context in empirical entrepreneurial research is perplexing bearing in mind that entrepreneurship is a dynamic and contextual phenomenon (Shane and Venkataraman 2000).

Yet, recent works suggest that the moment is ripe for re-engaging historical dynamics, historical contexts and entrepreneurial processes (Cassis and Minoglou 2005; Landström and Lohrke 2010; Wadhwani and Jones 2014). While management scholars are calling for a "historic turn" (Álvaro-Moya and Donzé 2016), drawing upon the use of historical reasoning to understand nature and behaviour of firms, business historians are being challenged to show higher theoretical aspirations. As Álvaro-Moya and Donzé (2016) reflect, this historic turn is already taking place in a variety of management fields such as strategy, international business or family business among many others.

This emerging historic turn also offers a key opportunity to the emergence of research that appreciates the outstanding influence that the spatial and historical environment play in shaping not only entrepreneurial behaviour but also any other kind of organizational phenomenon. The valuable positioning of research at the crossroads between business history and management has been already demonstrated in other research domains -family business, networks, international business, business groups or innovation- by scholars sensitive to 
historicism ${ }^{1}$. As the present special issue of the Journal of Evolutionary Studies in Business stresses, appreciating the influence of the context must encourage for more work that explores environmentally-embedded business strategies and processes, attends to the microsphere that matters for organizational behaviours and, in short, investigates and appreciates how different organizations are and act when research acknowledges how different is the world itself.

Mindful of the advancements aforementioned, the purpose of this article is to further encourage dialogue between management and business history taking as an example the domain of entrepreneurship. For that aim, the first section reviews past historical and management contributions to the entrepreneurship literature. This review will demonstrate how theoretically distant management and business history studies have addressed similar issues within entrepreneurship. Offering a renewed view on this issue, the article then follows on to develop insight into three particular entrepreneurial debates where the dialogue between management and business history seems to be highly promising: networks, corporate entrepreneurship and international entrepreneurship. These three debates constitute just a small example of the wide range of debates in which a multidisciplinary perspective combining business history and management can be extraordinarily fruitful.

\section{Entrepreneurship as a research field}

Academic research on entrepreneurship has grown extensively over the last decades. Although the first theoretical contributions to the field date back to more than a century, since the mid-1980s the entrepreneurial phenomenon has reached a central, promising role in the

\footnotetext{
${ }^{1}$ Amatori (2009); Amatori and Jones (2003); Bucheli and Wadhwani (2014); Cassis and Minoglou (2005); Colli (2011, 2012); Colli et al. (2003, 2013); Colli and Rose (2008); Fernández Pérez and Colli (2013); Fernández Pérez and Rose (2009); Jones and Khanna (2006); Jones and Wadhwani (2006, 2007, 2008); Kipping and Üsdiken (2008); Landström and Lohrke (2010); Lazonick (2003); McCraw (2006); O'Sullivan and Graham (2010); Roscoe et al. (2013); Rose (1995, 1999); Wadhwani and Jones (2014).
} 
understanding of economic growth and innovation processes of both economies and firms. This growing interest has generated a highly fragmented field of research, characterized by the proliferation of multiple theories and concepts borrowed from several disciplines such as sociology, psychology, economics or management. Moreover, past studies have used multiple levels of analysis -individuals, firms, industries, countries- and different methodical approaches (Low and MacMillan 1988; Acs and Audretsch 2003; Aldrich 2005; Busenitz et al. 2003; Cooper 2003; Stevenson and Jarillo 1990; Veciana 2007) possibly limiting the width and breath of insight within the domain. Undoubtedly, while the confluence of different perspectives has enriched the field, it has also generated substantial dispersion that has prevented the consolidation of a unified research paradigm. As a consequence, there is no unified theoretical basis for the study of entrepreneurship (Eckhardt and Shane 2003) and our knowledge about central issues like corporate behaviour, entrepreneurial opportunities, the skills and characteristics of people that identify and pursue them as well as the influence of the external environment on these activities remains limited. In short, the black box of entrepreneurship has not been opened up yet.

Making sense of this complex landscape is not easy. Indeed, it is complicated even when we try to define the concept of entrepreneurship (Cuervo, Ribeiro and Roig 2006), or when attempting to distinguish entrepreneurs from non-entrepreneurs. This is what Schumpeter already highlighted when commenting on the criticism for its inaccuracy in defining this agent: "the distinctive element is readily recognized as soon as we make clear to ourselves what it means to act outside the pale of routine. The distinction between adaptive and creative response to given conditions may or may not be felicitous, but it conveys an essential point; it conveys an essential difference." (Schumpeter [1951] 1968, 259). 
What is entrepreneurship? For some, entrepreneurship implies an organizational process that consists of setting up a new organization (Gartner 1985, 1988). Others, however, have stressed that this phenomenon has much more to do with personal capabilities, especially those related to the discovery of opportunities that lie behind the market (Kirzner 1973; Stevenson and Jarillo 1990). While the debate is still actual, one of the most well-known definitions of entrepreneurship relates to the process of discovery, exploration and exploitation of opportunities to introduce new goods and services, ways of organizing, markets, processes, and raw material through organizing efforts that previously had not existed (Venkataraman 1997; Shane and Venkataraman 2000; Eckhardt and Shane 2003). These 'opportunities' have become the commonly cited unit of analysis in entrepreneurship over the last years (Hsieh et al. 2007).

According to this approach -not exempt from criticism- the entrepreneur is an innovative agent seeking to exploit new business opportunities with the ultimate goal of making a profit. $\mathrm{He} / \mathrm{she}$ is also an agent that has the potential to change the trajectory of a market or industry and therefore is the essential source of dynamism in the economy (Schumpeter 1928, 1934, 1942; Drucker 1985). But, in order to exploit business opportunities, the individual capacity of this agent is not the only factor: the economic, political and cultural context is also decisive (Shane 2003). Therefore, to study and properly understand entrepreneurship we should go beyond the individual level and recognize, at least, three dimensions: the entrepreneur as an individual, the company as an organization and the external environment which ultimately influences the decisions and determines how to act. In this endeavour, management and business history have a common path with some shared concerns: the study of processes of economic change, business agents and institutions and their interaction with the political, 
economic and social environment that surrounds them (Cassis and Minoglou 2005; Jones and Zeitlin 2008). The next two subsections show how both disciplines approached entrepreneurship research.

\section{Historical approaches to Entrepreneurship.}

Historical reasoning has played a profound role in the early development of entrepreneurship research (Landrström and Lohrke 2010, 8). The importance of historical approaches to entrepreneurship and their development can be summarized into five major milestones.

Firstly, historical perspectives have played a key role in giving entrepreneurship its first and more precise economic meaning. Although classical and early neoclassical economic thought in the nineteenth and early twentieth centuries eschewed both the notion of entrepreneurship and the legitimacy of historical reasoning, a number of social scientists with some historical awareness such as Jean Baptiste Say and Richard Cantillon started promoting the theoretical development of entrepreneurship.

Yet, as a whole, entrepreneurship remained strongly connected to the classical and early neoclassical economic thought. In the early twentieth century a number of historians and historical sociologists reversed this unfortunate trend. They brought entrepreneurship back into the research agenda considering it as a dynamic phenomenon. This was the second milestone in the shared journey between historical research and entrepreneurship. Sociologists and historians of the German school, especially Max Weber, questioned the validity of the typically static theories of classical and neoclassical economics and called for the use of historical perspectives to explain industrial change and the dynamics of capitalism (Hodgson 2001; Jones and Wadhwani 2007). Weber's major contributions were reflected in the work The Protestant Ethic and the Spirit of Capitalism (1904/1970), which highlighted the 
influence of certain religious influences -in particularly Protestant ethics- in building a work ethos. In his work, Weber argued that the Protestantism and its positive attitude to work motivated entrepreneurship and thus facilitated the development of modern capitalism. In later works, this author extended his interpretation of the entrepreneurial phenomenon by establishing a clear distinction between the entrepreneur and the bureaucrat: for Weber, the "rationality" of industrial capitalism is eminently bureaucratic and the entrepreneur, as a dynamic and energetic agent, was the only one who can keep bureaucracy at bay (Swedberg 1998; Landström and Benner 2010).

Within this historical sociologist approach to entrepreneurship Schumpeter is particularly outstanding. He argued that historical research should have a logical priority in the study of entrepreneurship (Schumpeter 1949). Schumpeter -who represents the third landmark in the historical study of entrepreneurship along with the Harvard School- proposed a continuous exchange between the history and theory of entrepreneurship so that the primary task of the researchers should be to develop a historical understanding of this complex phenomenon. According to Schumpeter, the essence of entrepreneurship went a step beyond the one proposed by Say. The Schumpeterian entrepreneur is essentially an innovative agent, responsible for the process of creative destruction, a concept he popularized as a way to describe the transformation that accompanies all innovation and that defines the dynamic character of capitalism. According to Schumpeter (1934), the entrepreneur is able to respond to a particular opportunity through innovation understood as a process of substitution of some products, processes or organizational forms for new ones, that is, through the creation of "new combinations" of resources. 
The Centre for Research on Entrepreneurial History, at Harvard University, further developed the essence of Schumpeterian thinking. Following the recommendations of this author, in the 1940s a group of researchers became interested in the entrepreneur and the obvious interlinks between this actor and the influence of the historical, institutional and social environment on economic development. Led by Arthur Cole, the Harvard Center for Research on Entrepreneurial History joined a group of historians, sociologists and economists who fuelled entrepreneurship research from a multidisciplinary perspective. Cole pointed out the guidelines to be followed by the scientific research on entrepreneurship. These guidelines included the biographies of businessmen and the history of their companies; the analysis of different types of business; the study of business leaders in each industrial sector; and the study of entrepreneurship in different historical stages (Veciana 2007).

The journal Explorations in Entrepreneurial History became the main channel of diffusion of the Centre. There were some other important contributions outside the journal as the work developed by Leland Jenks $(1944,1949)$ and Thomas Cochran $(1950,1960)$. Both authors analyzed the influence of entrepreneurial attitude on economic development. They were interested in social, cultural and institutional factors as determinants of entrepreneurship, and they considered entrepreneurship as an engine for economic development. After Jenks and Cochran's contributions, historical research on entrepreneurship focused on the study of regional differences, using the comparison as a tool to highlight the influence of historical and cultural factors on entrepreneurial behaviour (Sass 1978). This "regionalist" view of entrepreneurship is the fourth milestone mentioned in the historical trend of entrepreneurship. David Landes was a prominent author within the approach focused on regional differences. In one of his most famous studies, Landes attributed the slowness of the nineteenth century 
French economy to the conservative attitudes of the French entrepreneurs. According to Landes, these French entrepreneurs were determined by the predominance of family businesses, considered poorly dynamic (Landes 1949). There were some other historians engaged in studying entrepreneurship across countries. Sawyer (1954), Ranis (1955), Hirschmeier (1964) and Gerchenkron $(1962,1966)$ could be quoted as the main references.

Since the late 1970s, the historical approach on entrepreneurship weakened. The entrepreneur as an individual became the most common level of analysis while regional, sectorial or national studies were often disregarded in the mainstream entrepreneurship and management literature (Jones and Wadhwani 2006). While psychologists, sociologists and management scholars focused on the individualistic approach to entrepreneurship, economic historians devoted to emerging disciplines like cliometrics and the analysis of large professionally managed corporations following Alfred D. Chandler's path (1962). The most significant example of this shift in the research agenda was the disappearance of the journal Explorations in Entrepreneurial History. Significantly the journal changed its name and aim to become Explorations in Economic History, a publication focused on the new quantitative studies (Landström and Benner 2010).

However, there were some interesting exceptions to this trend. By the end of the 20th century, new generations of economic historians recovered the lost research agenda, paying new attention to the historical context. This is the fifth milestone in this shared journey between historical research and entrepreneurship. New studies explored the influence of the institutional framework in the development of entrepreneurship and, thus, in the economic growth (Baumol 1988, 1990; North 1990; Davis and North 1971; North and Weingast 1989; Murmann 2003). 
Values and culture also returned to the research agenda (Casson 1986, 1991, 1995, 2003; Walker 1986; Morawaska 1996; Tennenbaum 1993). Biographies of entrepreneurs, an ancient tradition among economic historians, and historical studies on companies, have also played a key role in bringing back the historical approach to entrepreneurship's contemporary research agenda. Another stream of recent research, rooted in Chandler's approach (1962), has focused on entrepreneurship at an organizational level (corporate entrepreneurship). This approach studies how the historical context affects the entrepreneurial behaviour of organizations and identifies the factors that promote or hinder innovation in large companies (Hounshell and Smith 1988; Graham and Schuldiner 2001; Cuff 2002; Lazonick 2003; Díaz Morlan 2009).

Another debate among business historians from a point of view that acknowledges the primary influence of the historical and spatial contexts refers to the correlation between entrepreneurial determinants and the positive or negative link to economic growth.

Specifically, and regarding less developed regions, historical research has played a profound role. Literature on the case of Southern Europe is abundant and multiple debates have arisen. One of most well-known streams, rooted on economic development literature, has focused on the existence or absence of an entrepreneurial spirit in less developed countries. As entrepreneurship is considered a prerequisite for development, the "absence of entrepreneurship" argument has been used by some authors to explain the slowness of development in countries of Southern Europe (Tortella 1994, 1996). This appreciation was in fact the core of the position hold by Gabriel Tortella, regarding Spain, later criticised by others. This debate has its roots in the early twentieth century when intellectuals linked to the Generation of '98 and the political Regenerationism attributed the slow economic development of Spain to the absence of an entrepreneurial spirit. Almost a century later, the 
debate was recovered by Gabriel Tortella $(1994,1996)$ who defended this argument by pointing out that the low educational levels in conjunction with certain social and cultural values associated with the so-called "castizo" model had been the main factors preventing the emergence of a true entrepreneurial ethos in Spain. The weakness of Spanish entrepreneurship constituted, for this author, the fundamental explanation for the slow economic development of the country in the nineteenth and early twentieth century. The Tortella's thesis was immediately criticized by Sudrià (1995) and, ten years later, Valdaliso (2005) noted that the roots of the slow economic growth had much more to do with institutional problems than with the mere lack of entrepreneurship. Tortella (2000) ended up nuancing his initial position to finally incline himself to this latter view. Thus, the final conclusion of this debate leads us to the statement that "education improves the quality of entrepreneurship rather than entrepreneurship itself" (García Ruiz and Toninelli 2010, 8).

In recent years, the Spanish economic historiography has tried to go deeper into the study of entrepreneurship, its determinants and its contribution to economic growth, using existing theoretical literature and, in many cases, drawing on quantitative indicators allowing results to be contrasted nationally and internationally (Valdaliso and Garcia Ruiz 2013). Relevant contributions in this line of research are Tortella, García Ruiz Ortiz-Villajos and Quiroga (2009), Díaz Morlán (2009), Garcia Ruiz (2010), Tortella, Quiroga and Moral-Arce (2011) and Tortella and Quiroga (2012). Taken together, this group of works highlights how the slow Spanish economic development appears not to be due to the absence of entrepreneurship but rather to the combination of factors such as geography, the slow growth of the internal market and its lack of integration and, above all, the lack of an optimal institutional and supportive framework including the prevailing low educational levels. These factors favoured 
unproductive combinations at the expense of business efficiency and competitiveness of companies and the Spanish economy as a whole.

The study of the determinants of entrepreneurship can also be seen in other South European countries. García Ruiz and Toninelli (2010) provide evidence on Spain, Italy, Greece as well as Latin America showing the wide range of factors that determine the quality and success of the entrepreneurial function and define its distinct typologies. Education, kinship networks, family and, interestingly, the capacity to enhance technological transfer, appear to be key factors that lie beyond the existence of ambitious entrepreneurs in countries where institutional rigidities have been recurrent obstacles to economic development.

\section{Management approaches to Entrepreneurship}

During the 1970s, deep technological and industrial changes led researchers to question the efficiency of large corporations. This significant moment re-launched theoretical and policy driven discussions on entrepreneurship and those around the relevance of small and medium sized enterprises. In spite of growing attention paid to the large industrial corporation, management scholars focused on the entrepreneur and the small entrepreneurial business. As a consequence the first journals in entrepreneurship and small entrepreneurial organizations appeared: Journal of Small Business Management in 1963, American Journal of Small Business in 1975, renamed Entrepreneurship Theory and Practice in 1988, Journal of Business Venturing, created in 1985, Small Business Economics, in 1989 and Entrepreneurship and Regional Development in 1989 (Cooper 2003).

The new field of research on entrepreneurship focused on four aspects that, in most cases, excluded the space-time coordinates: (i) the individual traits of the entrepreneur, (ii) their behaviour, (iii) the environment in which they operate and (iv) the existence, identification 
and exploitation of entrepreneurial opportunities. In the following discussion, these perspectives are developed.

(i) According to the "traits approach," the entrepreneur displays particular and distinctive features in terms of propensity to take risks, creativity, imagination or need for achievement. In summary, he has got an "entrepreneurial personality" (McClelland 1961; Kihlstrom and Laffont 1979; Schere 1982; Bridge, O'Neill and Cromie 2003). In consequence, this approach takes the view that it is possible to identify the most likely individuals to start businesses (Brockhaus 1975, 1980; Hocher and Ganrose 1985). In short, this individualistic approach implies that the "entrepreneur is born, not made." This simplistic statement has received many criticisms. William Gartner, Ian MacMillan and Murray Low, among the most prominent, pointed out that this research was "inherently useless" in the absence of a comprehensible understanding of the context surrounding every entrepreneur (Gartner 1988; Low and MacMillan 1988; Shaver 1995).

(ii) During the 1980s and 1990s there was a second approach based on cognitive models of human behaviour. It was an alternative to the previous individualistic approach focused on the entrepreneurial personality (Mason and Harvey 2013). This approach includes two main fields of research. The first applied the concept of self-efficacy, i.e. the belief in one's capabilities. It has been used to explain why some engage and others do not in start-up processes. It has also been used to explain differences in the performance of small and medium sized businesses. Drawing particularly on attitude-based models such as Ajzen's Theory of Planned Behaviour (Ajzen 1988), this approach considers the intention of a particular individual as the best indicator or predictor of subsequent behaviour. Consequently, it can be used to anticipate the decision to undertake and to explain entrepreneurial behaviour (Krueger and Carsrud 1993; 
Krueger and Brazeal 1994; Kolvereid 1996; Lüthje and Franke 2003; Souitaris, Zerbinati and Al-Laham 2007). So, the study of "entrepreneurial intentions" focuses on the distinctive character of the entrepreneur but it has received heavy criticism, both inside and outside the area of business organization (Gartner 1988).

(iii) The previous criticism led to new approaches. One of them focused on the environment. Studies, mostly quantitative, sought to link the entrepreneurial phenomenon with the external environment in which it operates. Technological change, industrial structure, the institutional framework or geographical context itself are some of the factors that have been identified as determinants of entrepreneurship. The work of Tushman and Anderson (1986), Hannan and Freeman (1987), Acs and Audretsch (1990), Grant (1996), Dobbin and Dowd (1997) and McMillan and Woodruff (2002), among others, are particularly representative of this approach. However, they have also received criticism. For example Shane (2003), points out that this approach continues to rely on sole determinants to develop insight into the complexity of entrepreneurial activity. The context alone does not determine or explain entrepreneurship. It also requires the action of individuals that identify and exploit opportunities.

(iv) A more comprehensive explanation of the entrepreneurial phenomenon should therefore consider together the environment, individuals and businesses (Shane 2003; Shane and Venkataraman 2000). This is precisely the core of the recent stream of research in entrepreneurship which focuses on the study of sources of opportunities, the process of discovering and exploiting these opportunities as well as individuals who discover and exploit them (Shane and Venkataraman 2000; Shane 2003). Indeed, business opportunities have become the most frequent approach within the area of entrepreneurship analysis and have 
gathered a vast body of literature difficult to categorize (Hsieh, Nickerson and Zenger 2007). Despite the growing interest, this research lacks a unified theory and a clear definition of concepts. Within this approach focused on opportunities, major contributions have ranged from perspectives related to the psychological traits of individuals ("trait-based perspectives") to the analysis of the economic, social, institutional and technological environment in which opportunities arise (Popp and Holt 2013).

\section{At the crossroads: business history and management}

Is there any intersection between the empirical evidence provided by business history and the theoretical and conceptual reasoning provided by management? The answer is a resounding yes and this article attempts to encourage dialogue between them. History provides the proper ground for discussing theoretical problems by offering the space-time coordinates in which the entrepreneurial phenomenon effectively operates. Meanwhile, management offers solid theoretical and conceptual tools that help us to understand explain and analyze entrepreneurial experience in its various expressions. Drawing on both history and management theory together constitutes a valuable tool to advance the study of entrepreneurship, contrasting existing theories and bringing new ideas that, in turn, develop new ones (Casson and Godley 2005).

Without denying the wide range of debates in entrepreneurship research in which bridging business history and management theory is potentially rewarding, this article provides the example of three of them: networks, corporate entrepreneurship and international entrepreneurship. They both offer a real opportunity to respond to the "historic turn" and to build a "theoretical history" and a "historical theory". Indeed, although the three debates have been successfully developed during the last decades by management scholars, the very nature 
of these debates, and their remaining gaps, point out the valuable contribution that history can offer.

\section{Entrepreneurship and Networks}

The effects of the interaction within a network are now well recognized to play a significant role in the shaping and forming of entrepreneurial processes, practices and outcomes (Aldrich and Zimmer 1986). Network relationships are known to enable, constrain and stimulate entrepreneurial activity, through providing connections and access to knowledge, information, physical and monetary assets. Indeed, having a network of relationships can be a powerful asset and one which within the entrepreneurial setting facilitates change and the development of organizations. So through activating their links, individuals make entrepreneurship happen, or not as the case might be.

Literature on networks is wide as debates have grown extensively over the last decades. Management scholars have played a profound role in this issue, building a powerful theoretical and empirical background that can be categorized into three distinctive perspectives, including three essential components of networks: the "structural" approach, the "relational" approach and the "cognitive" approach. These approaches provide three different views on the role played by networks on entrepreneurship.

(i) Network structure is defined as the pattern of relationships that are engendered from the direct and indirect ties between actors (Hoang and Antoncic 2003). This approach to network research has focused on determining how this pattern of relationships between entrepreneurs and other individuals affects the performance of the entrepreneurial venture. This view assumes that both, the network size and the position of the entrepreneurs in the network (centrality), influence the transfer of information and resources and, therefore, may increase 
or decrease the likelihood of success of the enterprise. Research in this field has obtained contradictory conclusions. Regarding the position of the entrepreneur in the network (and according to network density), there are two opposing views. The first, based on the contributions of Coleman (1988, 1990), suggests that dense networks with highly interconnected actors promote the development of trust between its members which, in turn, benefits the sharing of resources and information (Semrau and Werner 2013). In contrast, research by Burt $(1982,1997,2005)$ highlights the advantages of a loose network with disconnected members. This perspective indicates that an actor that has a central position in the network (that connects other members unrelated to each other) is more likely to access a variety of resources and may obtain the benefits from bridging structural holes (the absence of ties between actors) (Semrau and Werner 2013).

From the viewpoint of the network size, findings are neither coincident (Hoang and Antoncic, 2003; Jack, 2010). Some authors have noted that the size of the network is positively related to the access to resources. Thus, it is expected that an extensive network provides a greater amount (Aldrich et al. 1987; Liao and Welsch 2005) and a greater variety of resources for entrepreneurs (Grandi and Grimaldi 2003; Greve and Salaff 2003). The reasoning behind this proposal is that, because people differ with respect to their stock of knowledge and resources, including more people in a network should also increase the variety of resources available for new entrepreneurs (Greve and Salaff 2003). This is especially true in the early stages of development of a company, when the network size is small and its actors are mainly limited to members of the family, friends and co-workers (Reagans and Zuckerman 2008). However, not always a greater size means better access to resources. Once the network has reached a considerable size, the inclusion of new members may provide the entrepreneur with redundant 
resources and information, therefore hardly valid for the exploitation of new opportunities (Semrau and Werner 2013). Conversely, other studies indicate that the size of the network does not have a decisive impact on business performance (Batjargal 2003, 2005).

(ii) In contrast to the structuralist approach, the relational perspective is concerned with the content and nature of personal relationships that entrepreneurs built through the history of their interactions. While it is accepted that relationships to others are important for entrepreneurs because of the benefits they bring, for some time now it has been said that we simply do not know enough about how such links influence organizations and the role they play in firm emergence, evolution and development (Elfring and Hulsink 2007; Hoang and Antoncic 2003; Jack 2010; Slotte-Kock and Coviello 2010). We know that in the early stages those individuals with whom the entrepreneur is more likely to interact with, will be people he/she has an association or experience of dealing with such as family, friends and close personal contacts often referred to as strong ties and with whom he/she has developed trust over time through loyal and mutual commitments (Elfring and Hulsink 2007; Newbert et al. 2013; Smith and Lohrke 2008). Such strong ties are particularly important at the beginning of the venture because they provide access to critical resources, in addition to emotional and practical support (Aldrich et al. 1987; Lechner and Dowling 2003). But we also know that as organizations emerge, networks of strong ties are constraining and inefficient (Hills, Lumpkin and Singh 1997; Ibarra 1993; Lechner and Dowling 2003). Hence, entrepreneurs are encouraged to develop networks based on weaker ties (Hansen 2002; Rowley, Behrens and Krackhardt 2000). This is because such networks offer the opportunity for diversity in information and resources and connections to other social systems (Aldrich et al. 1987; Elfring and Hulsink 2007). So over time an entrepreneur should expand his/her network by 
adding weak ties. Indeed, the common assumption of the extensive benefits this can bring appears well grounded both theoretically and practically.

While it is generally accepted that networks of relationships play a key role in the development of entrepreneurial organizations, debates about the applicability of strong ties and the role they play over time continue to exist (Elfring and Hulsink 2007; Newbert, Tornikoski and Quigley 2013; Simsek, Lubatkin and Floyd 2003). The literature leads us to believe that weak ties play a more prominent role than strong ties, primarily because they offer specific advantages and connections to other social systems as well as the likelihood of new resources (Burt 1992; Ibarra 1993; Jack 2005). However, recent studies have implied that actually context may play a bigger role in influencing who the entrepreneur interacts with and why. For instance, Stam et al. (2014) found that homogeneous networks of strong ties are better suited to entrepreneurs operating in developing economies. Likewise, Xin and Pierce (1996) argued that a network primarily formed of strong ties is crucial to entrepreneurial success in contexts with little institutional support. Indeed in the absence of institutional support -generally found in developed economies- the challenges faced by entrepreneurs may well motivate them to develop their ventures with the support of a close network of trustworthy partners (Arregle et al. 2015; Bruton et al. 2008; Kwon and Arenius 2010).

(iii) Finally, Nahapiet and Ghoshal (1998) offer a third perspective to study the influence of networks on entrepreneurship: the cognitive approach. This dimension assumes the existence of shared values and common paradigms that allow for the construction of meanings and ways of acting. This institutionalist vision, contrary to the concept of entrepreneurship as an individualistic process, proposes that social networks provide entrepreneurs a set of rules that determine their behavior. The "institutionalized" rules set a socialized behavior of the 
entrepreneur who must subordinate individual desires to group objectives. Thus, the network generates confidence and pushes entrepreneurs to take a long term view, realizing that their interests will be satisfied to the extent that collective purposes are achieved.

Based on this cursory literature review on networks, it can be concluded that the structural approach has received more attention than the relational one (Hoang and Antoncic 2003; O'Donnell et al. 2001). We know a lot about the structural features associated with networking (Kim and Aldrich 2005). However, we still do not know enough about how a network is actually formed, and how it develops and changes because few studies have addressed entrepreneurial networks as an evolutionary process (Anderson, DrakopoulouDodd and Jack 2010; Slotte-Kock and Coviello 2010). The literature acknowledges the scarcity of studies exploring the relationship between networks and business results beyond the start-up phase (Renzulli and Aldrich 2005), as well as the content and nature of the relationships rooted within a network (Uzzi 1997; Rodan and Galunic 2004). Regarding the strength of ties, discussion on the role and importance of strong ties not only in the establishment but also in the subsequent development of an organization remains (Newbert et al. 2013).

In sum, one of the major challenges facing network research is to explore how entrepreneurs create and activate social networks, how they manage their evolution and how the development of networks determines the performance of the business. If this is the aim, the way forward in the research seems to point to two key tools: (i) qualitative studies and (ii) perspectives of processes that take into account the evolutionary character of the entrepreneurial process. (i) Firstly, to explore the dynamic nature of social networks, their evolution and their impact on organizations' performance requires adopting a qualitative 
perspective. From qualitative evidence, the case studies are research tools particularly suitable if the researcher seeks to deepen and analyze a phenomenon in its real environment. In the words of Eisenhardt (1989), the case study is "a research strategy that focuses on understanding the dynamics present within single settings" (p. 534). Within the field of entrepreneurship, case studies are a very popular research method (Bryman 2004). They stand out as being very useful to show how networks are embedded in the development of entrepreneurial ventures and to provide a detailed explanation of the context in which entrepreneurs operate (Eisenhardt 1989; Eisenhardt and Graebner 2007). Business history is undoubtedly familiar with this research methodology and therefore is well situated to advance the research gaps described above. Business history is used to provide detailed descriptions of specific cases of enterprises and entrepreneurs, to recognize the influence of the past on present events, to provide an understanding of the space-time contexts surrounding entrepreneurship and to work with a wide range of both oral and written sources. Thus, business history should be called to participate in advancing research on networks.

(ii) Secondly, management literature has emphasized the importance of studying networks over time (Anderson et al. 2010; Slotte-Kock and Coviello 2010). It has been claimed that networks are not static but rather dynamic and flexible, and they change over time as new ties are activated or others are excluded. Therefore, if the research goal is to appreciate the relational and evolutionary nature of networks, studies should adopt a long-term perspective. Otherwise it would be very difficult to appreciate the causal mechanisms underlying networks, the processes, the nature of the ties, the actual reasons that motivate an entrepreneur to create a network and its consequences and, especially, the actual environment in which networks are created and develop over time (Coviello 2005). Although we already have some 
longitudinal studies in this area they are still scarce, and the research agenda is called to cover this gap. In this endeavor, business history appears again as a tool of great potential. The history of companies and entrepreneurs is an excellent research field as long as we accept it not only as the ground to test theory and evidence, but also as the origin of new ideas to expand our knowledge. As the example demonstrates historical research may be able to provide new answers to questions like how, when and why a network is created, develops and changes over time.

\section{Corporate Entrepreneurship}

Besides the creation of new businesses, entrepreneurship is also a process that takes place in established organizations. Since the late 1980s the study of entrepreneurial behavior within established organizations has gained growing scholarly attention (Miller 1983; Sharma and Chrisman 1999; Zahra 1986, 1995, 1996; Zahra and Covin 1995). Corporate Entrepreneurship as a research field dates back to the work of Robert Burgelman (1983) who defined it as the set of entrepreneurial activities that take place within existing companies. Although research on this field started earlier, Burgelman was the first to place corporate entrepreneurship in the organization and management literature. The growing interest in this issue has resulted in a proliferation of theoretical and conceptual perspectives that have caused conceptual perplexity (Morris and Kuratko 2002; Hornsby et al. 2002; Parker 2011). Sharma and Chrisman (1999) helped to solve this problem by reconciling the research agenda and an active process of standardizing and clarifying terminology in this field. After a thorough review of the plethora of concepts, Sharma and Chrisman (1999) define corporate entrepreneurship as "the process whereby an individual or a group of individuals, in association with an existing organization, create a new organization or instigate renewal or innovation within that organization, create a 
new organization or promotes renewal or innovation within the same" (p. 18). From this definition, three main processes related to corporate entrepreneurship are implicitly assumed: (i) strategic renewal -significant changes in the organization's strategy or structure-, (ii) corporate venturing -the creation of new organizations either inside or outside the existing organizational domain-, and (iii) innovation - intrinsic to both strategic renewal and corporate venturing-.

Apart from the terminology, other important concern of scholars has been measuring corporate entrepreneurship as a way to distinguish companies that are entrepreneurial from others that are not. The most successful effort in this issue has been the model proposed by Miller (1983) based on the concept of "entrepreneurial orientation". He defined that "entrepreneurial orientation" emerges from the interplay of three distinct components: (i) innovation, (ii) risk taking and (iii) proactivity. Thereby, an entrepreneurial organization is defined as the one that innovates, assumes risks in its activities and shows a forward-looking approach by introducing new products or services ahead of the competition and by anticipating future needs or preferences of the market (Lumpkin and Dess 1996, 1997; Miller 1983, 770). While these concepts maybe applicable to other types of entrepreneurial processes, they undoubtedly capture the essence of corporate entrepreneurship (Zahra and Covin 1995).

Scholarly literature also has also investigated how entrepreneurial orientation can be stimulated or constrained by sets of either external and/or internal environmental dimensions (Kearney, Hisrich and Roche 2009). Scholars appear to believe that the most consistent intraorganizational dimensions are: the organizational structure (Morris and Jones 1999), decision making (Bozeman and Kingsley 1998; Nutt 2005), motivation (Baird and St-Amand 1995; 
Hornsby et al. 2002) and organizational culture (Covin and Slevin, 1991). In general, it is assumed that organizations with less formalized structures, more flexible and decentralized decision-making procedures, a lower degree of formalization in the control system and higher rewards and motivation also demonstrate higher levels of entrepreneurship. Regarding the external environment, research has demonstrated that external conditions have a strong, if not deterministic, influence on the existence and effectiveness of entrepreneurial activity (Covin and Slevin 1991; Kearney, Hisrich and Roche 2009). Dynamism, hostility and heterogeneity are the environmental dimensions most cited by research (Lumpkin and Dess 1996). In essence, dynamism and heterogeneity of the environment reflect the uncertainty faced by an organization as a result of political, social, technological and economic changes. Hostile environments, meanwhile, refers to the degree of rivalry and competitive intensity and the abundance or scarcity of resources in the market -environmental hostility increases as competition and resources scarcity become intense-. Dynamism, hostility and complexity of the environment tend to be positively related to the entrepreneurial orientation of organizations (Kearney, Hisrich and Roche 2009).

The business history literature on corporate entrepreneurship has evolved in parallel and with little interaction with the burgeoning managerial literature on the field (Zahra et al. 1999; Jones and Wadhwani 2008). During the 1950s, scholars like Arthur Cole and Edith Penrose approached the study of business performance using the Schumpeterian approach to innovation. Since then, all attempts to reintegrate the corporation in historiography draw undoubtedly on the seminal work of Chandler. The well-known professor of business history at Harvard University noted that the modern industrial corporation could be considered entrepreneurial and innovative in the Schumpeterian sense (Chandler 1990). In his book The 
Visible Hand, Chandler described the emergence of large corporations as an entrepreneurial response to the opportunities arising from technological and market changes. In Strategy and Structure references are also found to the way that a corporation can be considered an innovative entity: the stories of DuPont, General Motors, Sears and Standard Oil show clear examples of companies making strategic decisions, anticipating market trends and adapting to structural change, -processes that Chandler presented in a chapter entitled "organizational innovation". The separation of ownership and management, the professionalization of management and the new corporate governance structures were all evidences of innovative behaviors that also meant a revolution in the structure and functioning of large industrial and service companies in the United States, Germany, France, Japan and the United Kingdom in the years preceding World War II (Fernández Pérez 2014). However, Chandler also noted that extent of management control, by itself, might not be enough to make the corporation an innovative and entrepreneurial entity. In fact, with large historical evidence, Chandler confirmed proposals for organizational theory stating that large corporations face greater obstacles to innovation due to technological lock-ins and routine and cultural rigidities (Brown and Eisenhardt 1995; Jones and Wadhwani 2008). As Cuff (2002) pointed out, the work of Chandler should not be interpreted as the separation between business history and entrepreneurship but rather as a reformulation of study on entrepreneurship beyond the individual to conceive the organization as the unit of analysis. The work of Chandler constitutes therefore the first and most recognized attempt to characterize the phenomenon of corporate entrepreneurship from a business history approach.

Following Chandler, a number of business historians developed research on the large managerial enterprise. In fact, until the 1980s the most recurrent unit of analysis in business 
history research, especially American, was essentially the corporation (Amatori 2006). From the countless case studies of companies in many countries and in different historical periods we have inherited a better understanding of innovation within large enterprises, and how the historical context determines corporate behavior. However, most of the research output has grown separately from other disciplines in the social sciences and, in particular, from the theoretical contributions of management (Zahra, Jennings and Kuratko 1999). This lack of interaction has limited results in both areas: in history it results in absence more advance theories, and in management theory it originates the lack of historical contextualization. Redirecting research towards a common point between the two disciplines offers the possibility of enriching the study of corporate entrepreneurship. It is undoubtedly a task that requires recognizing the usefulness of the concepts proposed by management and the evidence provided by business history. Within corporate entrepreneurship research, business history constitutes an especially valuable tool in understanding entrepreneurship in both, large and small organizations, as a process of discovery and exploitation of opportunities that evolves, ultimately, as a result of the combined influence of external and organizational environmental conditions.

\section{International Entrepreneurship}

Entrepreneurship and international business are two fields of research with a growing interface (McDougall and Oviatt 2000; Jones and Khanna 2006). A cursory review of current academic contributions on both fields confirms it. Some of the recently proposed definitions of entrepreneurship include certain components of internationalization: "the competitive behaviors that drive the market process" (Davidsson 2005, 6); "the introduction of new economic activity that leads to change in the market place" (Davidsson 2005, 8), or "new 
business creation, that means introducing a new product, entering a new market or both" (Sathe 2003, 5). Lu and Beamish $(2001,567)$ also add that "internationalization is an act of entrepreneurship, because it is a strategy in search of opportunities for firms growth and wealth by expanding into new markets".

The connection between these two research fields, entrepreneurship and international business, has given rise to a research interface known as "international entrepreneurship". Zahra and George $(2002,261)$ define international entrepreneurship as "the process of creatively discovering and exploiting opportunities that lie outside a firm's domestic markets in the pursuit of competitive advantage". Even though the initial literature on this topic focused on new firms -the so-called born global firms- or companies that experienced some critical event -the so-called born-again born global companies- (Coviello and Munro 1995), international entrepreneurial opportunities can arise in established firms (Zahra and George 2002; Zahra et al. 2000). Building upon this accepted definition, the academic domain of international entrepreneurship has moved beyond the study of young and yet small firms to cover any kind of business of any king of ownership. Further, internationalization is thus seen as an entrepreneurial process as described by Oviatt and McDougll (2005).

However, this emerging research field seems to face the same challenges that have affected entrepreneurship and international business in their own individual trajectory: fragmentation in the theoretical state of art and a very few regard to the historical reasoning. Although historical approaches have provided some pioneering thoughts into these two research fields, both entrepreneurship and international business seem to have become areas dominated almost exclusively by the management abstract reasoning. 
Yet, business history and, particularly, the history of transnational corporations can contribute to many extant debates on international entrepreneurship, a research field which is growing and becoming as fertile as its two independent components. We acknowledge that there is much work to do on improving understanding of how entrepreneurs and entrepreneurial organizations operate in different institutional environments, how the home environment may shape the way in which organizations internationalize their operations, how international organizations build institutional arrangements or create and build in networks to face problems related to international business activities and how these organizational arrangements, embedded in different institutional contexts in home and host countries, are relatively enduring and influential over time.

Moreover, while much has been done to identify drivers of international entrepreneurship (Zahra and George 2002), the role of family has largely been ignored as it has in the entrepreneurship literature in general (Aldrich and Cliff 2003; Kellermanns and Eddleston 2006; Kellermanns et al. 2008). As it has been demonstrated that families have significant influence on decision making and performance of their businesses (Fernández Pérez and Lluch 2015; Mustakallio et al. 2002), it would be expected that they could also strongly affect international entrepreneurship. Although the relationship between family ownership and internationalization has been a controversial topic in the literature, some studies note that family ownership is a relevant and positive component in the internationalization of businesses (Colli et al. 2013; Puig and Fernández 2010; Zahra 2005). Thus, the study of the internationalization of family business is another field of research in which interdisciplinary approaches between history and management can shed light on the contribution of family firms to exploiting international entrepreneurial opportunities. 


\section{Management Theory and History: final reflections}

The entrepreneurial phenomenon is by nature multidisciplinary: it comprises human behaviors and personal attributes -studied mainly in the area of psychology and individual analysis-; social and cultural influences -often led by the field of sociology-; organizational processes and corporate strategies -economics and management interests-; but it also includes spatial and temporal dynamics determined by economic, industry and institutional conditions. Therefore, "history also matters". Due to the multidisciplinary character of entrepreneurship phenomenon, entrepreneurship research should also meet the same premise: been able to gather different approaches and methods but from a coherent and unified way. The challenge is therefore to aggregate contributions from different disciplines and endeavor on a shared path.

What does history offer to management theory and, respectively, management theory to history? Our argument is that history provides management theory with two core components: context and time.

The context brings to the forefront the spatial reality in which the phenomenon takes place and develops. Appreciating contextual circumstances allows for enriching any research as it involves taking into account as a whole the economic, social and institutional conditions of a given territory. In turn, this creates an appreciation of how these elements determine the performance of organizations or individuals. In short, the context offers the rich, complex reality in which all phenomena are embedded. Moreover, an understanding of context matters for the kind of generalizations we draw based on studies of a selected place as it restricts misleading assumptions. To appreciate the context leads to clearly assume that what is or has 
been successful at a particular place does not necessarily work in another, especially if its characteristics are significantly different. This appreciation achieves a critical role when we compare territories with different levels of development or with a different timing in its historical growth. Regarding the main topic of this article, entrepreneurship is far from being a flat phenomenon so that the way it happens, develops and changes over time has been distinct in early-developed regions and in late-developed ones. Indeed, late-developed regions have encouraged entrepreneurs to draw on organizational strategies and actions that might not be accessible in environments granted with inclusive institutions and well-performing markets. Drawing on personal relationships might be one the most outstanding examples of entrepreneurial strategies that have historically allowed business survival under uncertain environments (Casson 1999; Colli, Fernández Pérez and Rose 2003; Colli and Rose 1999; Fernández Pérez and Rose 2009; Granovetter 1995; Rose 1999). History also offers accurate descriptions of the timeframe within which crucial actors operate. Appreciating time determines a method of research that is necessarily dynamic, supplementing theory reasoning with a rich description of temporal processes and change dynamics that accompany any investigated phenomena. Moreover, reality is stubbornly dynamic so that time also acts as a core boundary constraint that should be taken into account when building "general theories" that attempt to transcend time and place. An understanding of historical context helps to correct for the empirical bias created when generalizations occur using a narrow band of evidence centered on the present (Jones and Wadhwani 2006).

Historicism is predicated on the understanding that the foundational basis of social or organizational behavior varies significantly over time and place. Thus, a theoretical generalization that may be valid today may not be applicable to behavior in the past or the 
future (Jones and Wadhwani 2006). The purpose of understanding this type of historical and geographic variation in context is not necessarily to create "general theories" that transcend all time and place but rather to create valid generalizations that hold true for meaningful boundaries of period and geography.

Management studies also have much to offer business history research. It is to be argued that management theorizing provides business historians with a valuable dose of abstraction that allows us to detach from the flat description of case studies in order to create generalizations that, although derived from actions grounded on specific time and place contexts, may be sensibly applicable to other similar periods and geographical contexts. As a consequence this has the potential to create valuable tools for analysis. The concepts and theories from management also bring induction techniques that help deepen the concrete evidences of case studies to develop interpretations and theoretical implications. This does not mean that business history should deny its descriptive essence. Far from it, and following the recommendations of Chandler, business historians need not to aspire becoming management theorists: whatever the theoretical aspirations of business historians, "traditional case studies must continue to provide the absolutely essential information on which any broad generalizations and concepts about the history of business and business institutions can be based' (Chandler 1984, 7).

In short, the engagement between management theory and business history must not involve the loss of the essence that defines each of the disciplines. Regarding business history, debates about what should constitute its essence continue. As this discipline is placed halfway between history and organization studies, one might ask what should be the right road to take: should business history address the multiple issues of history or, on the contrary, should it be 
placed as part of the scientific organizational research and so should it try to make valid generalizations on the trajectory of entrepreneurs and businesses? Perhaps the answer to this dilemma does not necessarily imply the renunciation of the tradition of historical, humanistic reasoning, nor the rejection of a closer engagement with the more contemporary theoretical and scientific apparatus. History and theory are not antithetical and the arguments for and the recourse to history in organization studies have been advocated in different ways: some advocate position history as the quintessential empirical field of theoretical reasoning and other, more ambitious, consider the historical evidence as a valuable tool to generate new ideas and build new theories. Whatever the way to bridge these two disciplines, their dialogue is invaluable for enriching research discussions and provides a key tool that fulfills the limitations and shortcomings of both.

\section{References}

Acs, Zoltan J., and David B. Audretsch. 1990. Innovation and Small Firms. Cambridge, MA: MIT Press.

Acs, Zoltan J., and David B. Audretsch, eds. 2003. Handbook of Entrepreneurship Research. An Interdisciplinary Survey and Introduction. Dordrecht: Kluwer.

Ajzen, Icek. 1988. Attitudes, personality, and behavior. Chicago, IL: Dorsey.

Aldrich, Howard E. 2005. "Entrepreneurship.” In The Handbook of Economic Sociology, edited by Neil J. Smelser and Richard Swedberg, 451- 477. Princeton, NJ: Princeton University Press.

Aldrich, Howard E., Rosen Ben, and William Woodward. 1987. "The Impact of Social Networks on Business Foundings and Profit: A Longitudinal Study." In Frontiers of Entrepreneurship Research, edited by Churchill, N.C. et al., 154-168. Wellesley, MA: Babson College.

Aldrich, Howard E., and Jennifer E. Cliff. 2003. "The pervasive effects of family on entrepreneurship: Toward a family embeddedness perspective." Journal of Business Venturing 18: 573-596.

Aldrich, Howard E., and Catherine Zimmer. 1986. "Entrepreneurship through social networks." In The art and science of entrepreneurship, edited by Donald L. Sexton and Raymond W. Smilor. Cambridge, MA: Ballinger. 
Álvaro-Moya, Adoración, and Pierre-Yves Donzé. 2016. "Business History and Management Studies." Journal of Evolutionary Studies in Business 1: 122-151.

Amatori, Franco. 2006. "Entrepreneurship." Imprese e Storia 34: 233-267.

Amatori, Franco. 2009. "Business History: State of the Art and Controversies." Entreprises et Histoire 55 (2): 11-23.

Amatori, Franco, and Geoffrey Jones. 2003. Business History around the World. Cambridge: Cambridge University Press Anderson, Alistair R., Sarah Drakopoulou-Dodd, and Sarah L. Jack. 2010. "Network practices and entrepreneurial growth." Scandinavian Journal of Management 26: 121-133.

Arregle, Jean-Luc, Batjargal, Bat, Hitt, Michael A., Webb, Justin W., Miller, Toyah. and Anne S. Tsui. 2015. "Family Ties in Entrepreneurs' Social Networks and New Venture Growth." Entrepreneurship Theory and Practice 39: 313-344.

Baird, Rose, and Réal St-Amand. 1995. Trust within the organization. Otawa, CA: Public Service Commission of Canada.

Batjargal, Bat. 2003. "Social capital and entrepreneurial performance in Russia: A longitudinal study." Organization Studies 24 (4): 535-556.

Batjargal, Bat. 2005. "Entrepreneurial versatility, resources and firm performance in Russia: A panel study." International Journal of Entrepreneurship and Innovation Management 5 (3/4): 284297.

Baumol, William J. 1988. Entrepreneurship, Management, and the Structure of Payoffs. Cambridge, MA: MIT Press.

Baumol, William J. 1990. "Entrepreneurship: productive, unproductive and destructive." Journal of Political Economy 98 (5): 893-921.

Bozeman, Barry, and Gordon Kingsley. 1998. "Risk culture in public and private organizations." Public Administration Review 58 (2): 109-118.

Bridge, Simon, O’Neill, Ken, and Stan Cromie. 2003. Understanding enterprise, entrepreneurship and small business. New York: Palgrave Macmillan.

Brockhaus, Robert H. 1975. "I-E locus of control scores as predictors of entrepreneurial intentions." Academy of Management Proceedings, 35th Annual Meeting, 433-5.

Brockhaus, Robert H. 1980. "Psychological and environmental factors which distinguish the successful from the unsuccessful entrepreneur: A longitudinal study." Academy of Management Proceedings, 40th Annual Meeting, 368-372.

Brown, Shona L., and Kathleen M. Eisenhardt. 1995. "Product development: Past research, present findings, and future directions." The Academy of Management Review 20 (2): 343-378. 
Bruton, Garry D., Ahlstrom, David, and Krzysztof Obloj. 2008. "Entrepreneurship in Emerging Economies: Where Are We Today and Where Should the Research Go in the Future." Entrepreneurship Theory and Practice 32 (1): 1-14.

Bryman, Alan. 2004. Social Research Methods. Oxford: Oxford University Press.

Bucheli, Marcelo, and Daniel Wadhwani. 2014. Organizations in Time: History, Theory, Methods. Oxford: Oxford University Press.

Burgelman, Robert A. 1983. "A Model of the Interaction of Strategic Behavior, Corporate Context, and the Concept of Strategy." Academy of Management Review 8 (1): 61-71.

Burt, Ronald S. 1982. Toward a Structural Theory of Action: Network Models of Social Structure, Perception, and Action. New York: Academic Press.

Burt, Ronald S. 1992. "The social structure of competition." In Networks and organizations: Structure, form, and action, edited by N. Nohria and R. G. Eccles, 57-91. Boston: Harvard Business School Press.

Burt, Ronald S. 1997. "A note on social capital and network content." Social Networks 19 (4): 355373.

Burt, Ronald S. 2005. Brokerage and Clousure. An Introduction to Social Capital. Nueva York: Oxford University Press.

Busenitz, Lowell W., West III G. Page, Shepherd Dean, Nelson Teresa, Chandler Gaylen N., and Andrew Zacharakis. 2003. "Entrepreneurship research in emergence: Past trends and future directions." Journal of Management 29: 285-308.

Cassis, Youssef, and Ioanna P. Minoglou. 2005. "Entrepreneurship in theory and history: State of the art and new perspectives." In Entrepreneurship in Theory and History, edited by Youssef Cassis and Ioanna Pepelasis Minoglou, 3-21. New York: Palgrave Macmillan.

Casson, Mark. 1986. "General Theories of the Multinational Enterprise: Their Relevance to Business History." In Multinationals: Theory and History, edited by Peter Hertner and Geoffrey Jones, 42-63. Brookfield: Gower.

Casson, Mark. 1991. The Economics of Business Culture. Oxford: Clarendon Press.

Casson, Mark. 1995. Entrepreneurship and Business Culture. Studies in the Economics of Trust, vol. 1. Aldershot, UK: Edward Elgar.

Casson, Mark. 1999. "The economics of the family firm." Scandinavian Economic History Review 47 (1): $10-23$.

Casson, Mark. 2003. The Entrepreneur: An Economic Theory. $2^{\mathrm{a}}$ ed. Cheltenham, UK: Edward Elgar. 
Casson, Mark, and Andrew Godley. 2005. "Entrepreneurship and historical explanation." In Entrepreneurship in Theory and History, edited by Y. Cassis and I. Minoglou, 25-60, New York: Palgrave.

Chandler, Alfred D. Jr. 1962. Strategy and Structure. Chapters in the History of the Industrial Enterprise. Cambridge, Mass.: MIT Press.

Chandler, Alfred D. Jr. 1984. "Comparative business history." In Enterprise and History: Essays in Honour of Charles Wilson, edited by D. C. Coleman and P. Matthias, 3-26- Cambridge: Cambridge University Press.

Chandler, Alfred D. Jr. 1990. Scale and scope: The dynamics of industrial capitalism. Cambridge: MA: Harvard University Press.

Cochran, Thomas. 1950. "Entrepreneurial Behavior and Motivation." Explorations in Entrepreneurial History 2: 304-307.

Cochran, Thomas. 1960. "Cultural Factors in Economic Growth." Journal of Economic History 20: 515-530.

Coleman, James S. 1988. "Social capital in the Creation of Human Capital." American Journal of Sociology, Supplement: 95-120.

Coleman, James S. 1990. Foundations of Social Theory. Cambridge, MA: Belknap Press.

Colli, Andrea. 2011. "Business History and Family Business Studies: From Neglect to Cooperation." Journal of Family Business Management 1 (1): 14-25.

Colli, Andrea. 2012. "Contextualizing Performances of Family Firms: The Perspective of Business History." Family Business Review 25 (4): 1-15.

Colli, Andrea, Paloma Fernández Pérez, and Mary B. Rose. 2003. "National Determinants of Family Firms Development: Family Firms in Britain, Spain, and Italy in the Nineteenth and Twentieth Centuries." Enterprise and Society 4 (1): 28-64.

Colli, Andrea, Esteban García-Canal, and Mauro F. Guillén. 2013. "Family character and international entrepreneurship: A historical comparison of Italian and Spanish 'new multinationals'." Business History 55 (1): 119-138.

Colli, Andrea, Carole Howorth, and Mary B. Rose. 2013. "Long-term perspectives on family business." Business History 55 (6): 841-854.

Colli, Andrea, and Mary B. Rose. 1999. "Families and firms: The culture and evolution of family firms in Britain and Italy in the Nineteenth and Twentieth Centuries." Scandinavian Economic History Review 47 (1): 24-47. 
Colli, Andrea, and Mary B. Rose. 2008. "Family Business." In The Oxford Handbook of Business History, edited by Jones, Geoffrey and Zeitlin, Jonathan, 194-218. Oxford: Oxford University Press.

Cooper, Arnold C. 2003. "Entrepreneurship: The Past, the Present, and the Future." In Handbook of Entrepreneurship Research: An Interdisciplinary Survey and Introduction, edited by Zoltan Acs and David Audretsch, 21-34. Boston: Kluwer Academic Publishers.

Coviello, Nicole E. 2005. "Integrating qualitative and quantitative techniques in network analysis." Qualitative Market Research: An International Journal 8 (1): 39-60.

Coviello, Nicole, and Hugh Munro. 1995, "Growing the entrepreneurial firm: networking for international market development.” European Journal of Marketing 29 (7): 49 - 361

Covin, Jeffrey G., and Dennis P. Slevin. 1991. "A Conceptual Model of Entrepreneurship as Firm Behavior." Entrepreneurship, Theory and Practice 16 (1): 7-25.

Cuervo, Álvaro, Ribeiro, Domingo, and Salvador Roig. 2006. Entrepreneurship: conceptos, teoría y perspectiva. Valencia: Fundación Bancaja

Cuff, Robert D. 2002. "Notes for a Panel on Entrepreneurship in Business History." Business History Review 76 (1):123-132.

Davidsson, Per. 2005. Researching Entrepreneurship. New York: Springer.

Davis, Lance E., and Douglass C. North. 1971. Institutional Change and American Economic Growth. Cambridge: University Press.

Díaz Morlán, Pablo. 2009. Capitalistas y empresarios. El mercado de la función empresarial. Alicante: Publicaciones de la Universidad de Alicante.

Dobbin, Frank, and Timothy J. Dowd. 1997. "How Policy Shapes Competition: Early Railroad Foundings in Massachusetts.” Administrative Science Quarterly 42 (3): 501-529.

Drucker, Peter F. 1985. Innovation and Entrepreneurship: Practice and Principles. Nueva York: Harper \& Row.

Eckhardt, Jon, and Scott Shane. 2003. "Opportunities and entrepreneurship.” Journal of Management 29 (3): 333-349.

Eisenhardt, Kathleen. 1989. "Building Theories from Case Study Research." The Academy of Management Review 14 (4): 532-550.

Eisenhardt, Kathleen, and Melissa E. Graebner. 2007. "Theory Building from Cases: Opportunities and Challenges." Academy of Management Journal 50 (1): 25-32.

Elfring, Tom, and Willem Hulsink. 2007. "Networking by entrepreneurs: Patterns of tie formation in emerging organizations.” Organization Studies 28 (12): 1849-1872. 
Fernández Pérez, Paloma. 2014. "Presentación." In La profesionalización de las empresas familiares, edited by Paloma Fernández, 15-17. Madrid: LID.

Fernández Pérez, Paloma, and Andrea Colli, eds. 2013. The Endurance of Family Businesses: a Global Overview. Cambridge: Cambridge University Press.

Fernández Pérez, Paloma, and Andrea Lluch. 2015. Familias empresarias y grandes empresas familiares en América Latina y España: una visión de largo plazo. España: Fundación BBVA.

Fernández Pérez, Paloma, and Mary B. Rose, eds. 2009. Innovation and Entrepreneurial Networks in Europe. New York: Routledge-Fundación BBVA.

García Ruiz, José Luis. 2010. "El mayor empresario privado en la historia del sector automovilístico español." Entelequia 12: 295-308.

García Ruiz, José Luis, and Pier A. Toninelli, eds. 2010. The Determinants of Entrepreneurship: Leadership, Culture and Institutions. London: Pickering and Chatto.

Gartner, William B. 1985. "A conceptual framework for describing the phenomenon of new venture creation." Academy of Management Review 10 (4): 696-706.

Gartner, William B. 1988. "Who is an entrepreneur? is the wrong question." American journal of small business 12: 11-32.

Gerschenkron, Alexander. 1962. Economic Backwardness in Historical Perspective. A Book of Essays. Cambridge: Harvard University Press.

Gerschenkron, Alexander. 1966. Bread and democracy in Germany. Nueva York: H. Fertig.

Graham, Margaret B. W., and Alec T. Schuldiner 2001. Corning and the Craft of Innovation. Oxford: Oxford University Press.

Grandi, Alesssandro, and Rosa Grimaldi. 2003. "Exploring the networking characteristics of new venture founding teams." Small Business Economics 21 (4): 329-341.

Granovetter, Mark. 1995. "Coase Revisited: Business Groups in the Modern Economy." Industrial and Corporate Change 4 (1): 93-130.

Grant, Robert M. 1996. "Toward a Knowledge-Based Theory of the Firm.” Strategic Management Journal 17: 109-122.

Greve, Arent and Janet W. Salaff. 2003. "Social Networks and Entrepreneurship." Entrepreneurship Theory and Practice 28 (1): 1-22.

Hannan, Michael T. and John Freeman. 1987. "The Ecology of Organizational Founding: American Labor Unions, 1836-1985.” American Journal of Sociology 92: 910-943.

Hansen, Morten T. 2002. "Knowledge networks: Explaining effective knowledge sharing in multiunit companies." Organization Science 13: 232-248. 
Hills, Gerald E., G.T. Lumpkin, and Robert P. Singh. 1997. "Opportunity recognition: perceptions and behaviours of entrepreneurs." In Frontiers of Entrepreneurship Research, 203 - 218. Babson College, Wellesley, MA.

Hirschmeier, Johannes. 1964. The Origins of Entrepreneurship in Meiji Japan. Cambridge: Harvard University Press

Hoang, Ha, and Bostjan Antoncic. 2003. "Network-based research in entrepreneurship. A critical review." Journal of Business Venturing 18: 165 - 187.

Hocher, Arthur, and Cherlyn S. Ganrose. 1985. "Sources of motivation to choose employee ownership as an alternative to job loss." Academy of Management Journal 28: 860-875.

Hodgson, Geoffrey. 2001. How Economics Forgot History: The Problem of Historical Specificity in Social Science. London: Routledge.

Hornsby, Jeffrey S., Donald F. Kuratko, and Zahra, Shaker A. 2002. "Middle managers' perception of the internal environment for corporate entrepreneurship: Assessing a measurement scale." Journal of Business Venturing 17 (3): 253-273.

Hounshell, David A., and John K. Smith. 1988. Science and Corporate Strategy at Du Pont, 19021980. Cambridge: Cambridge University Press.

Hsieh, Chihmao, Jack A.Nickerson, and Todd R. Zenger. 2007. "Opportunity Discovery, Problem Solving and a Theory of the Entrepreneurial Firm.” Journal of Management Studies 44 (7): 1255-1277.

Ibarra, Herminia. 1993. "Personal Networks of Women and Minorities in Management: A Conceptual Framework." Academy of Management Review 18 (1): 56-87.

Jack, Sarah L. 2005. "The role, use and activation of strong and weak ties: a qualitative analysis." Journal of Management Studies 42 (6): 1233-1260

Jack, Sarah L. 2010. "Approaches to studying networks: implications and outcomes." Journal of Business Venturing 25 (1): 120-137.

Jenks, Leland H. 1944. "Railroads as an economic force in American development." Journal of Economic History 4: 18-20.

Jenks, Leland H. 1949. "Role structure of entrepreneurial personality." In Change and the Entrepreneur, 108-152. Research Center in Entrepreneurial History, Cambridge: Harvard University Press.

Jones, Geoffrey. 2008. "The lessons of business history: A handbook." Interview with S. Silverthorne. Harvard Business School Working Knowledge, 17 March. http://hbswk.hbs.edu/item/5849.html. Jones, Geoffrey, and Tarun Khanna. 2006. "Bridging history (back) into international business." Journal of International Business Studies 37: 453-68. 
Jones, Geoffrey, and R. Daniel Wadhwani. 2006. "Schumpeter's Plea: Rediscovering History and Relevance in the Study of Entrepreneurship." HBS Working Paper.

Jones, Geoffrey, and R. Daniel Wadhwani. 2007. Entrepreneurship and Global Capitalism. Cheltenham, UK and Northampton, MA, USA: Edward Elgar.

Jones, Geoffrey, and R. Daniel Wadhwani. 2008. "Entrepreneurship." In The Oxford Handbook of Business History, edited by Geoffrey Jones and Jonathan Zeitlin, 501-528. Oxford: Oxford University Press.

Jones, Geoffrey, and Jonathan Zeitlin. 2008. "Introduction.” In The Oxford Handbook of Business History, edited by Geoffrey Jones and Jonathan Zeitlin, 1-6. Oxford: Oxford University Press.

Kearney, Claudine, Robert Hisrich, and Frank Roche. 2009. "Public and private sector entrepreneurship: similarities, differences or a combination?" Journal of Small Business and Enterprise Development 16 (1): 26-46.

Kellermanns, Franz W., and Kimberly A. Eddleston. 2006. "Corporate entrepreneurship in family firms: A family perspective." Entrepreneurship: Theory \& Practice 30: 809-830.

Kellermanns, Franz W., Kimberly. A. Eddleston, Tim Barnett, and Allison Pearson. 2008. "An exploratory study of family member characteristics and involvement: Effects on entrepreneurial behavior in the family firm." Family Business Review 21: 1-14.

Kihlstrom, Richard E., and Jean J. Laffont. 1979. "A general equilibrium entrepreneurial theory of firm formation based on risk aversion." Journal of Political Economy 87: 719-748.

Kim, Phillip H., and Howard E. Aldrich. 2005. "Social Capital and Entrepreneurship." Foundations and Trends in Entrepreneurship 1 (2): 55-104.

Kipping, Matthias, and Behlül Üsdiken. 2008. "Business Hisoty and Management Studies.” In The Oxford Handbook of Business History, edited by Jones, Geoffrey and Zeitlin, Jonathan, 96-119. Oxford: Oxford University Press.

Kirzner, Israel M. 1973. Competition and entrepreneurship. Chicago: University of Chicago Press.

Kolvereid, Lars. 1996. "Prediction of employment status choice intentions." Entrepreneurship Theory \& Practice 21 (1): 47-57.

Krueger, Norris F., and Alan L. Carsrud. 1993. "Entrepreneurial intentions: applying the theory of planned behaviour." Entrepreneurship \& Regional Development 5 (4): 315-330.

Krueger, Norris F., and Deborah V. Brazeal. 1994. "Entrepreneurial Potential and Potential Entrepreneurs." Entrepreneurship theory \& practice 18 (3): 91-91.

Kwon, Seok-Woo, and Pia Arenius. 2010. "Nations of entrepreneurs: A social capital perspective." Journal of Business Venturing 25 (3): 315-330. 
Landes, David S. 1949. "French entrepreneurship and industrial growth in the nineteenth century." Journal of Economic History 9: 45-61

Landström, Hans, and Mats Benner. 2010. "Entrepreneurship research: a history of scholarly migration." In Historical Foundations of Entrepreneurship Research, edited by Hans Landström and Franz Lohrke, 15-45. Cheltenham, UK: Edward Elgar.

Landström, Hans, and Franz Lohrke, eds. 2010. Historical Foundations of Entrepreneurship Research. Cheltenham: Edward Elgar

Lazonick, William. 2003. "Understanding Innovative Enterprise: Toward the Integration of Economic Theory and Business History." In Business History around the World edited by Franco Amatori and Geoffrey Jones, 31-61. Cambridge: Cambridge University Press.

Lechner, Christian, and Michael Dowling. 2003. "Firm networks: External relations as sources for the growth and competitiveness of entrepreneurial firms." Journal of Entrepreneurship and Regional Development 15 (1): 1-26.

Liao, Jianwen, and Harold Welsch. 2005. "Roles of Social Capital in Venture Creation: Key Dimensions and Research Implications." Journal of Small Business Management 43 (4): 345362.

Low, Murray B., and Ian C. Macmillan. 1988. "Entrepreneurship: Past research and future challenges." Journal of Management 14 (2): 139-161.

Lu, Jane W., and Paul W. Beamish. 2001. "The internationalization and performance of SMEs." Strategic Management Journal 22: 565-586.

Lumpkin, G. Tom, and Gregory G. Dess. 1996. "Clarifying the entrepreneurial orientation construct and linking it to performance." Academy of management Review 21 (1): 135-172.

Lumpkin, G. Tom, and Gregory G. Dess. 1997. "Proactiveness versus competitive aggressiveness: Teasing apart key dimensions of an entrepreneurial orientation." In Frontiers of Entrepreneurship Research, edited by P. Reynolds, W. Bygrave, N. Carter, P. Davidsson, W. Gartner. C. Mason and P. Mcdougall, 47-58. Wellesley, MA: Babson College.

Lüthje, Christian, and Nikolaus Franke. 2003. "The 'making' of an entrepreneur: testing a model of entrepreneurial intent among engineering students at MIT." R\&D Management 33 (2): 135-147.

Mason, Colin, and Charles Harvey. 2013. "Entrepreneurship: Contexts, opportunities and processes." Business History 55 (1): 1-8.

McClelland, David C. 1961. The achieving society. New York: The Free Press.

Mccraw, Thomas K. 2006. "Schumpeter's Business Cycles as Business History.” Business History Review 80, 231-261. 
McDougall, Patricia P., and Benjamin M. Oviatt. 2000, "International Entrepreneurship: The Intersection of Two Research Paths.” Academy of Management Journal 43 (5): 902-906.

McMillan, John, and Woodruff, Christopher. 2002. "The Central Role of Entrepreneurs in Transition Economies." Journal of Economic Perspectives 16 (3): 153-170.

Miller, Danny. 1983. "The Correlates of Entrepreneurship in Three Types of Firms." Management Science 29 (7): 770-791.

Morawaska, Ewa. 1996. Insecure Prosperity: Jews in Small-Town Industrial America, 1880-1940. Princeton, NJ: Princeton University Press.

Morris, Michael H., and Foard F. Jones. 1999- "Entrepreneurship in established organisations: the case of the public sector." Entrepreneurship Theory and Practice 24 (1): 71-91.

Morris, Michael H., and Donald F. Kuratko. 2002. Corporate Entrepreneurship: Entrepreneurial Development Within Organizations. Orlando, FL: Harcourt College Publishers.

Murmann, Johann P. 2003. Knowledge and Competitive Advantage: the Coevolution of Firms, Technology and National Institutions. New York: Cambridge.

Mustakallio, Mikko, Autio Erkko, and Zahra Shaker. 2002. "Relational and contractual governance in family firms: Effects on strategic decision making." Family Business Review 15: 205-222.

Nahapiet, Janine, and Sumantra Ghoshal. 1998. "Social capital, intellectual capital, and the organizational advantage." Academy of management review 23 (2): 242-266.

Newbert, Scott L., Erno T. Tornikoski, and Narda R. Quigley. 2013. "Exploring the evolution of supporter networks in the creation of new organizations." Journal of Business Venturing 28 (2): 281-298.

North, Douglas. 1990. Institutions, Institutional Change, and Economic Performance. Cambridge: Cambridge University Press.

North, Douglas, and Barry Weingast. 1989. "Constitutions and Commitment: The Evolution of Institutions Governing Public Choice in Eighteenth-Century England." Journal of Economic Performance 49: 803-32.

Nutt, Paul C. 2005. "Comparing public and private sector decision-making practices." Journal of Public Administration Research and Theory 30: 1-30.

O’Sullivan, Mary, and Margaret B. Graham. 2010. "Moving Forward by Looking Backward: Business History and Management Studies.” Journal of Management Studies 47 (5): 775-790.

O'Donnell, Aodheen, Gilmore Audrey, Cummins Darryl, and David Carson. 2001. "The network construct in entrepreneurship research: a review and critique." Management Decision 39 (9): 749-760. 
Oviatt, Benjamin. M., and Patricia P. McDougall. 2005. "Defining international entrepreneurship and modeling the speed of internationalization." Entrepreneurship: Theory and Practice 29: 537554.

Parker, Simon C. 2011. "Intrapreneurship or entrepreneurship?” Journal of Business Venturing 26 (1): 19-34.

Popp, Andrew, and Robin Holt. 2013. "The presence of entrepreneurial opportunity." Business History 55 (1): 9-28.

Puig, Nuria, and Paloma Fernández Pérez. 2010. "A Silent Revolution: The Internationalisation of Large Spanish Family Firms.” Business History 51 (3): 462-83.

Ranis, Gustav. 1955. "The Community-Centered Entrepreneur in Japanese Development." Explorations in Entrepreneurial History 7: 80-98.

Reagans, Ray E., and Ezra W. Zuckerman. 2008. "Why knowledge does not equal power: the network redundancy trade-off." Industrial and Corporate Change 17 (5): 903-944.

Renzulli, Linda A., and Aldrich Howard. 2005. "Who can you turn to? Tie activation within core business discussion networks." Social Forces 84 (1): 323-341.

Rodan, Simon, and Charles Galunic. 2004. "More than network structure: how knowledge heterogeneity influences managerial performance and innovativeness." Strategic Management Journal 25: 541-556.

Roscoe, Philip J., Allan Discua Cruz, and Carole Howorth. 2013. "How does an old firm learn new tricks? A material account of entrepreneurial opportunity.” Business History 55 (1): 53-72.

Rose, Mary B. Ed. 1995. Family Business, Aldershot: Edward Elgar.

Rose, Mary B. 1999. "Networks, values and business: the evolution of British family firms from the eighteenth to the twentieth century." Entreprises et Histoire 22 (2): 16-30.

Rowley, Tim, Behrens Dean, and David Krackhardt. 2000. "Redundant governance structures: An analysis of structural and relational embeddedness in the steel and semiconductor industries." Strategic Management Journal 21: 369-386.

Sass, Steven. 1978. "Entrepreneurial Historians and History: An Essay in Organized Intellect." Ph.D. diss., Johns Hopkins University.

Sathe, Vijay. 2003. Corporate entrepreneurship: Top managers and new business creation. Cambridge, UK: Cambridge University Press.

Sawyer, John. 1954. "The Social Basis of the American System of Manufacturing." Journal of Economic History 14: 361-79.

Schere, Jean L. 1982. "Tolerance of ambiguity as a discriminating variable between entrepreneurs and managers." Proceedings of the Academy of Management 42: 404-408 
Schumpeter, Joseph A. 1928. “The instability of capitalism.” Economic Journal 38: 361-386.

Schumpeter, Joseph A. 1934. The Theory of Economic Development. Cambridge: Harvard University Press.

Schumpeter, Joseph A. 1942. Capitalism, Socialism and Democracy. Nueva York: Harper and Brothers (Harper Edition 1976).

Schumpeter, Joseph A. (1949)1989. "Economic Theory and Entrepreneurial History." In Essays on Entrepreneurs, Innovations, Business Cycles, and the Evolution of Capitalism, edited by Richard Clemence, 253-272. New Brunswick: Transaction Publishers.

Schumpeter, Joseph A. (1951)1968. Ensayos. Barcelona: Oikos-Tau.

Semrau, Thorsten, and Arndt Werner. 2013. "How Exactly Do Network Relationships Pay Off? The Effects of Network Size and Relationship Quality on Access to Start-Up Resources." Entrepreneurship Theory and Practice 38 (3): 501-525.

Shane, Scott, and Sankaran Venkataraman. 2000. "The promise of entrepreneurship as a field of research." Academy of management review 25 (1): 217-226.

Shane, Scott. 2003. A General Theory of Entrepreneurship. The individual-opportunity Nexus. Massachusetts: Edward Elgar Publishing.

Sharma, Pramodita, and Sankaran J. Chrisman. 1999. "Toward a Reconciliation of the Definitional Issues in the Field of Corporate Entrepreneurship." Entrepreneurship Theory \& Practice 23 (3): $11-27$

Shaver, Kelly G. 1995. "The entrepreneurial personality myth.” Business and Economic Review 41: 20-23.

Simsek, Zeki, Michael H. Lubatkin, and Steven W. Floyd. 2003. "Inter-firm networks and entrepreneurial behavior: A structural embeddedness perspective." Journal of Management 29 (3): 427-442.

Slotte-Kock, Susanna, and Nicole Coviello. 2010. "Entrepreneurship Research on Network Processes: A Review and Ways Forward." Entrepreneurship Theory and Practice 34 (1) 31-57.

Smith, Delmonize A., and Franz T. Lohrke. 2008. "Entrepreneurial network development: Trusting in the process." Journal of Business Research 61 (4): 315-322.

Souitaris, Vangelis, Zerbinati, Stefania, and Andreas Al-Laham. 2007. "Do entrepreneurship programmes raise entrepreneurial intention of science and engineering students? The effect of learning, inspiration y resources.” Journal of Business Venturing 22 (4): 566-591.

Stam, Wouter; Arzlanian, Souren, and Tom Elfring. 2014. "Social capital of entrepreneurs and small firm performance: A meta-analysis of contextual and methodological moderators." Journal of Business Venturing 29: 152-173. 
Stevenson, Howard H., and J.Carlos Jarillo. 1990. "A paradigm of entrepreneurship: Entrepreneurial management.” Strategic Management Journal 11: 17-27.

Sudrià, Carles. 1995. "El desarrollo de la España contemporánea. Historia económica de los siglos XIX y XX.” Revista de Economía Aplicada 9: 171-176.

Swedberg, Richard. 1998. Max Weber and the idea of economic sociology. Princeton, NJ: Princeton University Press.

Tennenbaum, Shelley. 1993. A credit to their community. Detroit, MI: Wayne State University Press.

Tortella, Gabriel. 1994. El desarrollo de la España contemporánea. Historia económica de los siglos XIX y XX, Madrid: Alianza.

Tortella, Gabriel. 1996. "La iniciativa empresarial, factor escaso en la España contemporánea." In $L a$ empresa en la Historia de España, edited by Comín, Francisco and Martín Aceña, 49-60. Madrid: Civitas.

Tortella, Gabriel. 2000. "Prólogo.” In Los 100 Empresarios Españoles del siglo XX, edited by Torres, Emilio, 13-17. Madrid: LID Editorial.

Tortella, Gabriel; José Luis García Ruiz, José María Ortiz-Villajos, and Gloria Quiroga. 2009. Educación, instituciones y empresa. Los determinantes del espíritu empresarial. Madrid: Academia Europea de Ciencias y Artes.

Tortella, Gabriel; Gloria Quiroga, and Ignacio Moral-Arce. 2011. “¿El empresario nace o se hace? Educación y empresarialidad en la España contemporánea." Revista de Historia Económica, Journal of Iberian and Latin American Economic History 29 (1): 123-153.

Tortella, Gabriel, and Gloria Quiroga, eds. 2012. Entrepreneurship and Growth. An International Historical Perspective. Houndmills, Basingstoke: Palgrave Macmillan.

Tushman, Michael L., and Philip Anderson. 1986. "Technological Discontinuities and Organizational Environments." Administrative Science Quarterly 31 (3): 439-465.

Uzzi, Brian. 1997. "Social structure and competition in interfirm networks: the paradox of embeddedness." Administrative Science Quarterly 42: 35-67.

Valdaliso, Jesús M. 2005. "El espíritu emprendedor en España: un análisis histórico.” In La empresa y el espíritu emprendedor de los jóvenes, edited by Cuervo, Álvaro and Sastre, M. A., 115-148. Madrid: Ministerio de Educación, Cultura y Deportes.

Valdaliso, Jesús M., and José L. García Ruiz. 2013. "El espíritu empresarial en la historia económica española." Revista de Historia Industrial 51: 15-18.

Veciana, José M. 2007. "Entrepreneurship as a scientific research programme." In Entrepreneurship: Concepts, theory and perspective, edited by Álvaro Cuervo, David Ribeiro and Salvador Roig, 23-71. Heidelberg: Springer. 
Venkataraman, Sankaran. 1997. "The distinctive domain of entrepreneurship research." Advances in Entrepreneurship, Firm Emergence and Growth 3 (1): 119-138.

Wadhwani, Daniel, and Geoffrey Jones. 2014. "Schumpeter's Plea: Historical Reasoning in Entrepreneurship Theory and Research." In Organizations in Time: History, Theory, Methods, edited by Marcelo Bucheli and Daniel Wadhwani, 192-216. Oxford: Oxford University Press.

Walker, Juliet. 1986. "Racism, Slavery, Free Enterprise: Black Entrepreneurship in the United States before the Civil War." Business History Review 60 (3): 343-382.

Weber, Max. 1904/1970. The Protestant Ethic and the Spirit of Capitalism. London: Unwin University Books.

Xin, Katherine R., and Jone L. Pearce. 1996. "Guanxi: Connections as Substitutes for Formal Institutional Support." The Academy of Management Journal 39 (6): 1641-1658.

Zahra, Shaker A. 1986. "A canonical analysis of corporate entrepreneurship antecedents and impact on performance." Proceedings of the Academy of Management, 71-75.

Zahra, Shaker A. 1995. "Corporate entrepreneurship and financial performance: the case of management leveraged buyouts." Journal of Business Venturing 10 (3): 225-247.

Zahra, Shaker A. 1996. "Governance, ownership and corporate entrepreneurship: The moderating impact of industry technological opportunities.” Academy of Management Journal 39 (6): 17131735 .

Zahra, Shaker A. 2005. "Entrepreneurial Risk-Taking in Family Firms." Family Business Review 18 (1): 23-40.

Zahra, Shaker A., and Jeffrey G. Covin. 1995. "Contextual influences on the corporate entrepreneurship performance relationship: a longitudinal analysis." Journal of Business Venturing 10 (1): 43-58.

Zahra, Shaker A., and Gerard George. 2002. "International Entrepreneurship: The Current Status of the Field and Future Research Agenda." In Strategic Entrepreneurship: Creating an Integrated Mindset, edited by Hitt, M, Irel, D, Sexton, D and Camp, M., 255-88. Oxford: Blackwell.

Zahra, Shaker A., Daniel F. Jennings, and Donald F. Kuratko. 1999. "The antecedents and consequences of firm-level entrepreneurship: The state of the field." Entrepreneurship Theory and Practice 24 (2): 45-65.

Zahra, Shaker A., R. Duane Ireland, and Michel A. Hitt. 2000. "International Expansion by New Venture Firms: International Diversity, Mode of Market Entry, Technological Learning, and Performance.” Academy of Management Journal 43 (5): 925-50.

This is an Open Access article distributed under the terms of the Creative Commons Attribution-Non-Commercial-No Derivatives License (http://creativecommons.org/licenses/by-nc-nd/4.0/), which permits non-comercial re-use and distribution, provided the original work is properly cited, and is not altered or transformed in any way. 